\title{
Effect of endotoxin on colonisation of Campylobacter jejuni in infant mice
}

\author{
MARJA-LIISA HÄNNINEN
}

College of Veterinary Medicine, Department of Food and Environmental Hygiene, Hämeentie 57, 00550 Helsinki, Finland

\begin{abstract}
Summary. An infant mouse model has been used to investigate the colonisation of the intestine by Campylobacter jejuni and the effect of endotoxin (Escherichia coli O26: B6) on the initial stage of this process. Endotoxin injected 1 or $16 \mathrm{~h}$ before the bacterial challenge had no effect on the growth of campylobacters but endotoxin injected 4 to $10 \mathrm{~h}$ before the bacterial challenge caused a bacteriostatic effect on the growth of campylobacters which lasted for one day. The bacteriostatic effect was evident both in the small intestine and in the distal part of the intestine containing caecum and colon. The mechanism of the bacteriostatic effect of endotoxin could not be explained in the study, but is thought to be non-immunological because it developed so rapidly. Oral and parenteral iron administered as ammonium ferric citrate or iron dextran, respectively, were used in an attempt to reverse the bacteriostatic effect. High oral doses of iron $(0.5 \mathrm{mg}$ per animal) were effective but small doses $(0.5 \mathrm{mg}$ per animal) were ineffective. Parenteral iron administration had a delayed effect on the reversal of the bacteriostatic effect of endotoxin. Transferrin administered orally caused a clear bacteriostatic effect in both endotoxin pretreated and untreated mice. Campylobacter counts were always lower in the small intestine than in the large intestine both in control and in endotoxin pretreated mice. This indicates that the large intestine is the primary ecological niche where campylobacters colonise mice.
\end{abstract}

\section{Introduction}

During the last 10 years several animal models have been developed to mimic human campylobacter infection: these include mice (Field et al., 1981; Blaser et al., 1983; Kazmi et al., 1984; Fauchere et al., 1985; Lee et al., 1986; Yrios and Balish, 1986), rabbits (Caldwell et al., 1983) and chickens (Beery et al., 1988; Shanker et al., 1988). In experimental infections, infant animals are more susceptible than older animals to colonisation with campylobacters (Field et al., 1981). Gnotobiotic animals have been colonised persistently (224 days) with Campylobacter jejuni, but when the animals were allowed to acquire a more complex intestinal flora, the campylobacters were gradually eliminated (Yrios and Balish, 1986). Using an adult mouse model, Blaser et al. (1983) noted that a large inoculum of $10^{8}$ cells per animal was needed for colonisation. In many of the animal models, however, animals showed neither diarrhoea nor other clinical symptoms comparable with human campylobacter enteritis.

Colonisation of the intestinal tract by a patho-

Received 14 March 1989; accepted 20 April 1989. genic organism is the first stage in the pathogenesis of infection. In mice, campylobacters have been shown to be mucus colonisers (Field et al., 1981; Lee et al., 1986). Adhesion to intestinal epithelial cells could be the mechanism for intestinal colonisation by campylobacters, but no specific adhesins indicating this to be the case have been found in these organisms. In their spiral morphology and motility characteristics, campylobacters closely resemble normal intestinal microbiota inhabiting the mucous layer (Lee et al., 1986). The second stage in colonisation is the multiplication of the organism in special niches of the intestinal tract. In animal models, campylobacters colonise the intestinal tract from the stomach to the colon (Blaser et al., 1983; Field et al., 1984; Lee et al., 1986; Yrios and Balish, 1986), the highest counts of the organism being found in the caecum and colon. Host-microbe interactions play a significant role in colonisation and a variety of mechanisms at intestinal surfaces have evolved to resist colonisation by pathogens. Immunologically, the most important mechanism is the production of $\operatorname{IgA}$, which is secreted into the mucous layer. The non-immunological mechanisms important in counteracting colonisation are avail- 
ability of nutrients, an indigenous mucus-associated flora, and the secretion by intestinal epithelial cells of bacteriostatic and bacteriocidal substances like lysozyme and lactoferrin (McNabb and Tomasi, 1981). The importance of secretory $\operatorname{IgA}$ in the prevention of colonisation by campylobacters has been shown indirectly in human and animal studies (Lane et al., 1987; McSweegan et al., 1987). The role of non-immunological mechanisms in vivo is less well known.

In the present study, the effects of systemically injected endotoxin on the colonisation kinetics of C. jejuni strains in infant mice were examined. Endotoxin pretreatment is known to have immediate effects on host iron metabolism, i.e., on the kinetics of the iron-binding proteins, lactoferrin, transferrin and ferritin, in the body (Weinberg, 1978; Bullen, 1981). The effects of endotoxin in many aspects resemble the acute phase effects of infection caused by gram-negative bacteria.

\section{Materials and methods}

\section{Bacterial strains}

Three $C$. jejuni strains isolated from campylobacter enteritis were used : strain 2605 from a child, strain 12650 from an adult (both infections acquired in Finland) and strain $\mathrm{KH}$ from an adult infected in Central Europe. The strains were subcultured several times on Brucella Blood Agar (Bacto Brucella Agar, Difco, Detroit, MI) before storage at $-70^{\circ} \mathrm{C}$. Before use as an inoculum each strain was passaged once in mice.

\section{Animals}

The experiments were performed by permission of the Experimental Animal Committee of the College of Veterinary Medicine. NMRI mice purchased from Orion, Espoo, Finland, were used to establish a breeding colony. The animals were mated and infants 4-9 days old were used in the experiments. The mice were fed with antibiotic-free feed and given water ad libidum. The infants remained with their dams for the duration of the studies.

\section{Cultures and growth conditions}

Before use as an inoculum, the strains were grown microaerophilically in Brucella Broth (Bacto Brucella Broth, Difco) containing citrated sterile calf blood $5 \%$ at $37^{\circ} \mathrm{C}$ for $30-40 \mathrm{~h}$. Brucella agar with citrated calf blood $5 \%$ was used as a nonselective medium; for counting campylobacters from the animal tissues, the medium was supplemented with vancomycin (Vancocin; Eli Lilly Co, Indianapolis, IND) $10 \mu \mathrm{g} / \mathrm{ml}$, trimethoprim (Sigma Chemical Co, St Louis, MO) $5 \mu \mathrm{g} / \mathrm{ml}$, polymyxin B (Sigma) $2.5 \mathrm{IU} / \mathrm{ml}$ and cephalothin (Keflin; Eli Lilly)
$15 \mu \mathrm{g} / \mathrm{ml}$. All bacterial dilutions were in peptone water $0 \cdot 1 \%$.

\section{Inoculation of animals with bacteria}

A $1 \cdot 0-\mathrm{ml}$ tuberculin syringe fitted with a blunted 21 gauge needle was used to inoculate each animal intragastrically (i.g.) with $c .10^{4}$ campylobacter cells in $0 \cdot 1 \mathrm{ml}$ of peptone water. The inoculum was made by diluting the brucella broth culture in peptone water and its size was determined by plating in duplicate 10 -fold dilutions on brucella blood agar plates.

\section{Endotoxin and iron treatments}

Initially, different time intervals from 1 to $24 \mathrm{~h}$ between endotoxin injection and campylobacter inoculation were tested. In most cases, endotoxin (from Escherichia coli O26: B6) was injected intraperitoneally (i.p.), $6 \mathrm{~h}$ before the bacteria (the standard time interval). The endotoxin dose was 4 or $8 \mu \mathrm{g} /$ animal. Iron dextran (Pigfer, Orion Pharmaceuticals, Espoo, Finland), $0.5 \mathrm{mg}$ of iron/animal, was injected i.p. simultaneously with the bacteria. Ammonium ferric citrate, 0.05 or $0.5 \mathrm{mg}$ of iron/animal, was used as an oral iron treatment. The bacterial inoculum was diluted with an aqueous ammonium ferric citrate solution, and the suspension was immediately administered i.g. to the mice. Similarly, iron-free human transferrin (Sigma), $0 \cdot 1 \mathrm{mg} /$ animal, was administered i.g. to the mice.

\section{Counting of organisms in the tissues}

The animals were killed with $\mathrm{CO}_{2}$, their abdomens were opened, and their gastrointestinal tracts were removed. Either the whole intestine (from duodenum to rectum) or its separated parts-the small intestine (duodenum, jejunum and ileum) and the large intestine (caecum, colon and rectum)-were homogenised separately in 9 ml of peptone water with a Colworth Stomacher Lab Blender (Tekmar; Cincinnati, $\mathrm{OH}$ ). In some studies the small intestine was rinsed with $9 \mathrm{ml}$ of peptone water from a $10-\mathrm{ml}$ syringe fitted with a needle similar to that used for the oral inoculation in order to count separately campylobacters associated with the intestinal wall and those in the lumen. The rinsed small intestine was homogenised in the same manner as the unrinsed small intestine. The homogenates were serially diluted in peptone water and plated in duplicate on antibioticsupplemented brucella blood agar plates. In some experiments, campylobacters were also counted from homogenates of the liver, heart and spleen. After incubation for $48 \mathrm{~h}$ at $37^{\circ} \mathrm{C}$ the number of campylobacter colonies was counted.

\section{Statistical analysis}

The campylobacter counts of two or three animals were analysed each time. The statistical significance was assessed with Student's $t$ test or the paired $t$ test. 


\section{Results}

\section{Effect of endotoxin on growth of campylobacters}

The increases in campylobacter cfu's in the intestines of infant mice over a few days for the three strains 2605,12650 and $\mathrm{KH}$ are presented in figs. 1, 2 and 3. The animals remained colonised with campylobacters for at least 2 weeks. As seen in figs. $1 \mathrm{~A}$ and $1 \mathrm{~B}$, pretreatment of mice with endotoxin had a bacteriostatic effect on campylobacters which lasted for 26-32 h after endotoxin pretreatment. In most experiments, a time interval of $6 \mathrm{~h}$ between endotoxin injection and bacterial challenge was used. Endotoxin doses of 4 and $8 \mu \mathrm{g} /$ animal gave similar bacteriostatic responses. Although the bacteriostatic effect was evident from the cfu determinations for the whole intestine, a more pronounced bacteriostatic effect was seen in the small intestine when the cfu's of small intestine and large intestine were analysed separately (fig. 2 ). The mean duplication times of campylobacters between 2 and $20 \mathrm{~h}$ after inoculation counted in 12 experiments from the results of whole intestines for the three strains, were $4.45 \mathrm{SD} 1.5 \mathrm{~h}$ and $2.7 \mathrm{SD}$ $0.57 \mathrm{~h}$ in endotoxin pretreated and control groups, respectively. These differences were significant $(p<0.005)$. The mean duplication times in five experiments counted similarly for strains 12650 and $\mathrm{KH}$ from the cfu's of the small intestine, were $5.0 \mathrm{SD} 0.87 \mathrm{~h}$ and $2 \cdot 1 \mathrm{SD} 0.24 \mathrm{~h}$ in the endotoxin pretreated and control groups, respectively. The differences between these duplication times were again significant $(\mathrm{p}<0.005)$. In most cases, as seen in figs. 2 and 3 , greater numbers of campylobacter were found in the large intestine than in the small intestine. The preference for large intestine colonisation was even more pronounced when the counts were related to weight or area, as the small intestine weighs more and is much longer than the large intestine.

\section{Time interval between endotoxin pretreatment and campylobacter challenge}

Different time intervals from 1 to $16 \mathrm{~h}$ between endotoxin pretreatment and bacterial challenge were used to determine the duration of the bacteriostatic effect of the endotoxin. The results of these experiments (see table I) showed that an interval of $1 \mathrm{~h}$ was too short and one of $16 \mathrm{~h}$ too long for the bacteriostatic effect of endotoxin to be expressed at any time from 2 to $26 \mathrm{~h}$ after challenge. Endotoxin injected 3, 4 or $10 \mathrm{~h}$ before the bacterial challenge had a significant $(\mathrm{p}<0.01, \mathrm{p}<0.02, \mathrm{p}<$ $0 \cdot 05$, respectively) bacteriostatic effect which was
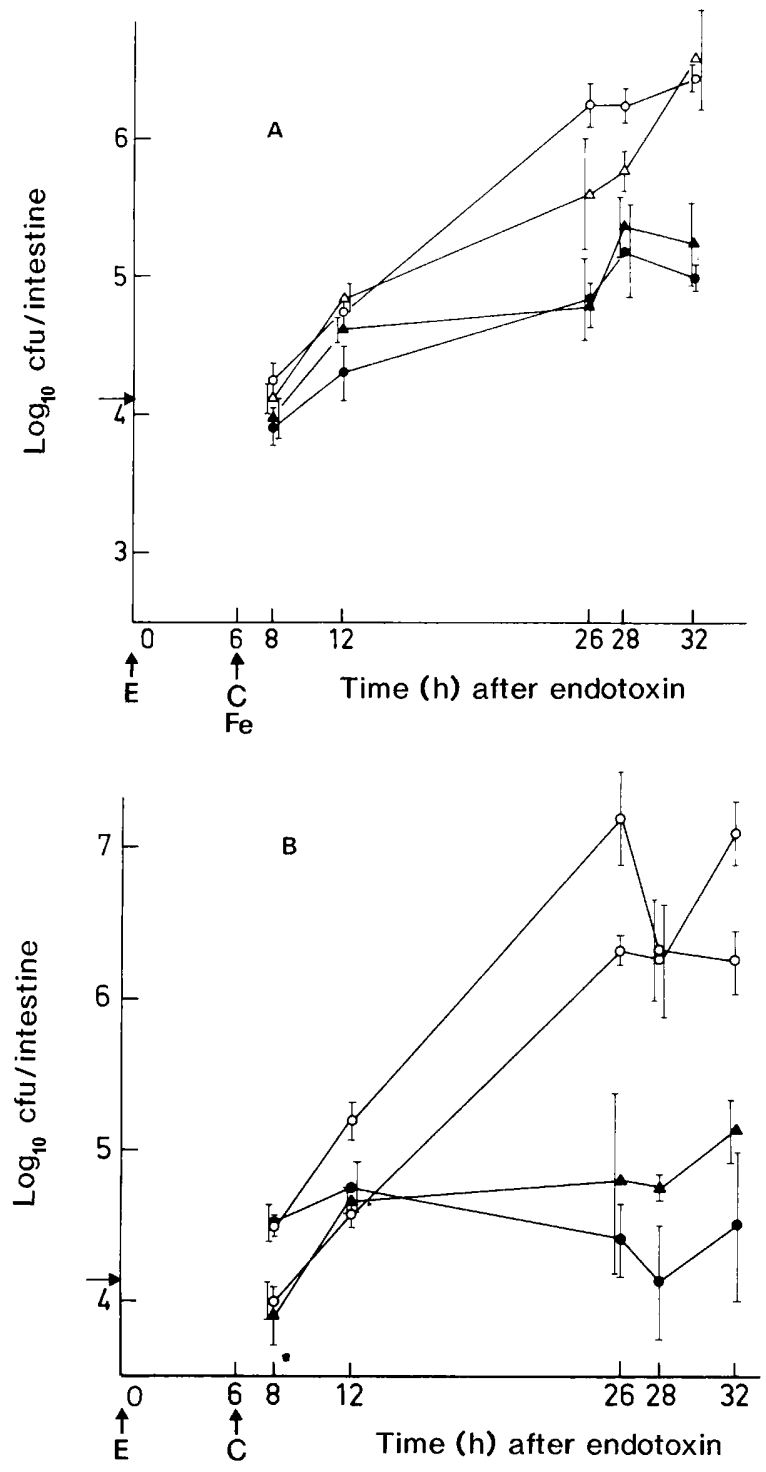

Fig. 1. Growth of $C$. jejuni strains 2605 (A) and 12650 (B) in the intestine (from duodenum to rectum) of infant mice with and without endotoxin (E. coli O26: B6; $4 \mu \mathrm{g}$ /animal i.p.) pretreatment : control groups 1 and $2 \mathrm{O}-\mathrm{O}$; endotoxin group $1 \mathbf{A}-$ $-\mathbf{A}$; endotoxin group $2-$; endotoxin + iron dextran (0.5 mg/animal i.p.) $\triangle-\triangle$. Each point represents the mean (SD) of two or three animals. The infecting dose is indicated by the arrow on the vertical axis and the time of endotoxin treatment (E) and the bacterial (C) or iron dextran ( $\mathrm{Fe}$ ) challenge time are indicated by arrows on the horizontal axis.

evident at most of the later assay times but not always in the early period $(2-5 \mathrm{~h})$ after challenge.

\section{Reversal of bacteriostatic effect of endotoxin}

Oral iron overload with ammonium ferric citrate, parenteral iron overload with iron dextran, and the 

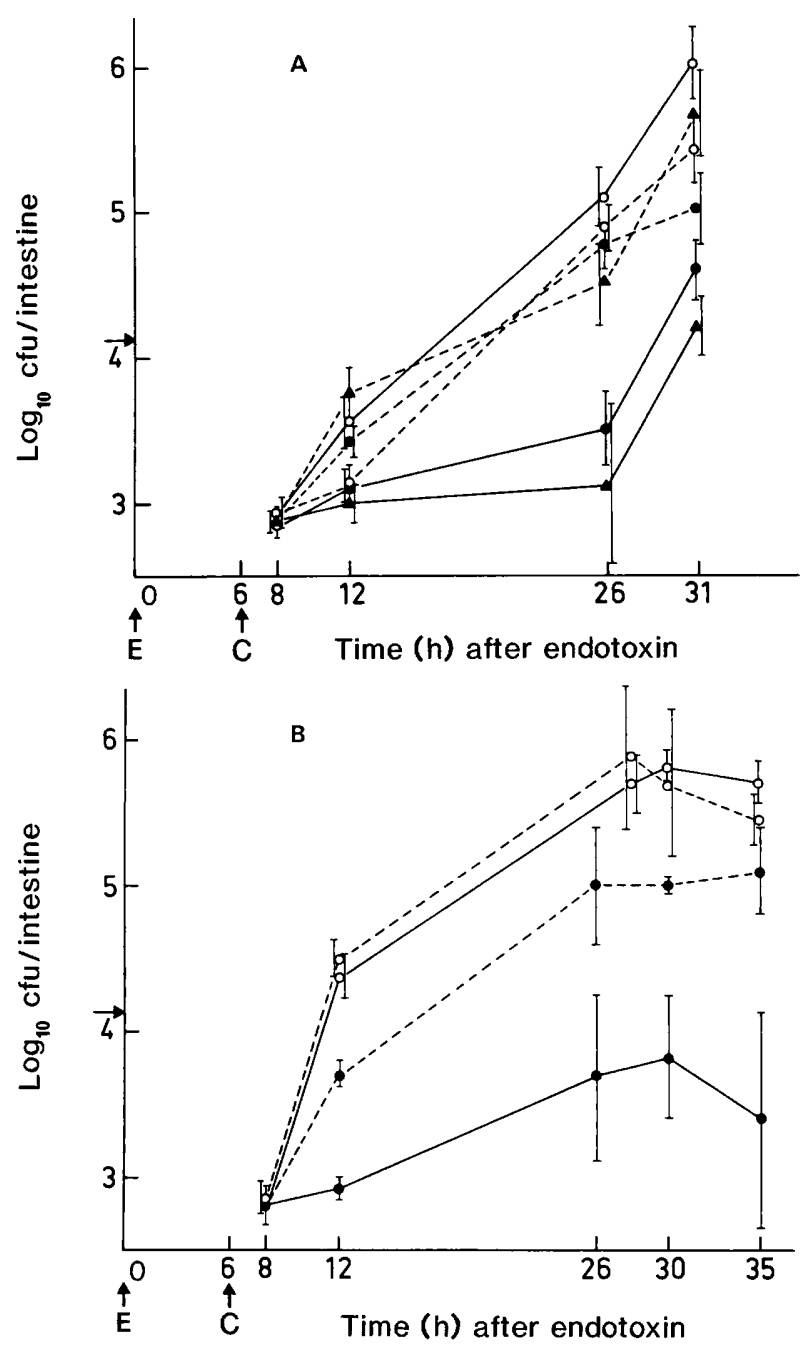

Fig. 2. Growth of $C$. jejuni strains 12650 (A) and KH (B) in the small intestine — and the large intestine - - - - of infant mice with and without pretreatment with endotoxin $(E$. coli $\mathrm{O} 26$ : $\mathrm{B} 6 ; 4 \mu \mathrm{g}$ /animal i.p.): control group $\bigcirc$; endotoxin group 1 $\mathbf{A}$; endotoxin group $2 \mathbf{O}$. The infecting dose is indicated by the arrow on the vertical axis and the times of endotoxin treatment (E) and bacterial challenge (C) are indicated by arrows on the horizontal axis.

effect of oral transferrin were tested for ability to reverse the bacteriostatic effect of endotoxin. As shown in table II, reversal of the bacteriostatic effect of endotoxin depended upon the dose of oral iron. A dose of $0.05 \mathrm{mg}$ of iron as ammonium ferric citrate did not reverse the bacteriostatic effect, but one of $0.5 \mathrm{mg}$ of iron as ammonium ferric citrate did.

The effect of parenteral iron dextran on the bacteriostatic effect of the endotoxin is presented in figs. $1 \mathrm{~A}$ and 3 . Viable counts on whole-intestinal specimens indicated that parenteral iron overload partly reversed the bacteriostatic effect of endotoxin and that the reversal could be delayed and was more evident during the latter part of the bacteriostatic period (fig. 1A). These differences were less clear when counts of duodenum and colon campylobacters were analysed separately (fig. 3 ). The mean duplication time of campylobacter strains 2605 , 12650 and $\mathrm{KH}$ in four experiments in the intestine of the mice which were treated with both endotoxin and iron dextran was $4.07 \mathrm{SD} 1.7 \mathrm{~h}$. Transferrin caused a similar bacteriostatic effect both in the experimental group dosed with transferrin and in the group pretreated with endotoxin and dosed with transferrin (table II).

\section{Campylobacter counts in the lumen and in the wall of} the small intestine

When the campylobacter counts of the contents of the lumen of the small intestine were determined separately from those of the wall of the small intestine, it was found that the counts of the intestinal lumen always correlated with those of the wall and that the intestinal contents contained fewer campylobacters than the intestinal wall. Oral or parenteral iron did not significantly affect the campylobacter counts in the intestinal lumen.

\section{Discussion}

Oral inoculation of campylobacters in infant mice caused a transient colonisation which usually lasted for 2 weeks. Because the purpose of the study was to analyse the kinetics of bacterial growth in the intestine at the initial stage of infection, the infectious dose used was low, about $10^{4}$ cells/ animal. In the control mice, campylobacter cfu's increased rapidly, the most pronounced increase being seen during the first day after inoculation. Endotoxin pretreatment had a bacteriostatic effect on the intestinal campylobacter counts which was detected during the first day after endotoxin pretreatment. This immediate effect of the endotoxin may be attributed to one or more of the many host effector molecules elicited by endotoxin which result in fever, hyposideraemia, complement activation, interferon production, and the induction of the production of soluble mediators from macrophages and mononuclear cells (Morrison and Ryan, 1987). These events take place a few hours after endotoxin treatment. Since specific antibody production usually starts only after several days, the bacteriostatic effect of the endotoxin in the present study must be associated with acute non-specific 

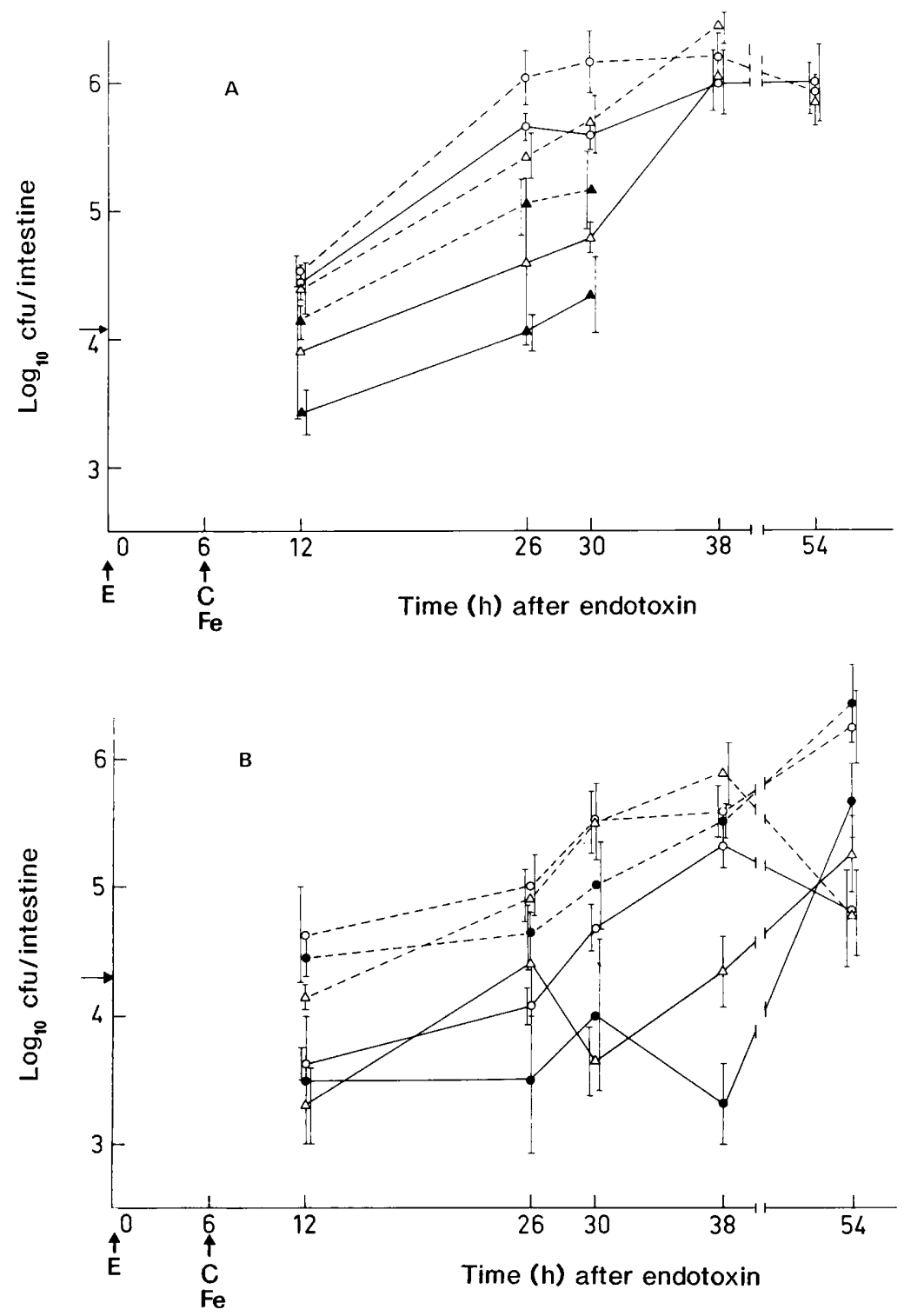

Fig. 3. Growth of $C$. jejuni strain 12650 (A) and $\mathrm{KH} \mathrm{(B)} \mathrm{in} \mathrm{the} \mathrm{small} \mathrm{intestine} \mathrm{—} \mathrm{or} \mathrm{large} \mathrm{intestine} \mathrm{-} \mathrm{-} \mathrm{-} \mathrm{of} \mathrm{infant} \mathrm{mice}$ following: $\bigcirc$ no treatment; $\Delta$, pretreatment with endotoxin $(E$. coli $\mathrm{O} 26: \mathrm{B} 6 ; 8 \mu \mathrm{g} /$ animal i.p. $) ; \Delta$ endotoxin + iron dextran $(0.5 \mathrm{mg} /$ animal i.p.). In A the cfu's in the endotoxin-pretreated group were counted between 12 and $30 \mathrm{~h}$, only. The infecting dose is indicated by the arrow on the vertical axis and the time of endotoxin treatment $(\mathrm{E})$, bacterial challenge $(\mathrm{C})$ and iron dextran $(\mathrm{Fe})$ doses by arrows on the horizontal axis.

resistance factors. Of the non-immunological bacteriostatic effects of endotoxin especially well known are fever and hyposideraemia, which are induced a few hours after endotoxin injection and last for about $24 \mathrm{~h}$ (Kampschmidt and Upchurch, 1962). The lowered iron saturation level in serum transferrin is associated with a decreased ability of the invading micro-organism to multiply in ironrestricted conditions and thus with a lowered pathogenicity of the organism for the host. This effect can be eliminated by simultaneous iron injection and saturation of transferrin iron binding capacity (Elin and Wolff, 1974). Endotoxin has been shown to increase the LD50 values by several log units in systemic infections with, for example, salmonellae, neisseriae, Candida albicans and mycobacteria (Weinberg, 1984). In mice, LPS pretreatment was shown to prevent the growth of $E$. coli 
Table I. Effect of time interval between endotoxin (E. coli O26: B6) pretreatment and bacterial challenge on growth of $C$. jejuni strain 12650 in intestine of infant mice

\begin{tabular}{|c|c|c|c|c|c|c|c|c|c|c|}
\hline \multirow{2}{*}{$\begin{array}{c}\text { Time }(h) \text { between } \\
\text { endotoxin pretreatment } \\
\text { and bacterial } \\
\text { challenge }\end{array}$} & \multirow{2}{*}{$\begin{array}{c}\text { Challenge } \\
\text { dose } \\
\text { (cfu) }\end{array}$} & \multirow{2}{*}{$\begin{array}{l}\text { Treatment of } \\
\text { animals }\end{array}$} & \multicolumn{8}{|c|}{$\begin{array}{c}\text { Campylobacters, } \log _{10} \text { cfu, mean (SD) intestine* at different times (h) } \\
\text { after bacterial challenge }\end{array}$} \\
\hline & & & 2 & 5 & 8 & 10 & 12 & 22 & 24 & 26 \\
\hline 1 & $1.1 \times 10^{4}$ & $\begin{array}{l}\text { Control } \\
\text { Endotoxin } \\
(4 \mu \mathrm{g})\end{array}$ & $\begin{array}{c}4 \cdot 10 \\
(0 \cdot 10) \\
4 \cdot 09 \\
(0 \cdot 11)\end{array}$ & $\ldots$ & $\begin{array}{c}4 \cdot 77 \\
(0 \cdot 27) \\
4 \cdot 56 \\
(0 \cdot 02)\end{array}$ & $\ldots$ & $\begin{array}{c}5 \cdot 34 \\
(0 \cdot 33) \\
5 \cdot 00 \\
(0 \cdot 65)\end{array}$ & $\begin{array}{l}\cdots \\
\cdots\end{array}$ & $\begin{array}{c}5 \cdot 51 \\
(0 \cdot 30) \\
5 \cdot 46 \\
(0 \cdot 09)\end{array}$ & \\
\hline 3 & $4.5 \times 10^{4}$ & $\begin{array}{l}\text { Control } \\
\text { Endotoxin } \\
(4 \mu \mathrm{g})\end{array}$ & $\begin{array}{c}4 \cdot 10 \\
(0 \cdot 16) \\
3 \cdot 50 \\
(0 \cdot 39)\end{array}$ & $\begin{array}{c}4 \cdot 30 \\
(0 \cdot 13) \\
4 \cdot 04 \\
(0 \cdot 05)\end{array}$ & $\ldots$ & $\begin{array}{c}5 \cdot 15 \\
(0 \cdot 16) \\
4 \cdot 30 \\
(0 \cdot 05)\end{array}$ & $\ldots$ & $\begin{array}{c}6 \cdot 21 \\
(0 \cdot 28) \\
5 \cdot 20 \\
(0 \cdot 20)\end{array}$ & $\ldots$ & $\begin{array}{c}6 \cdot 66 \\
(0 \cdot 23) \\
5 \cdot 70 \\
(0 \cdot 12)\end{array}$ \\
\hline 4 & $5.7 \times 10^{4}$ & $\begin{array}{l}\text { Control } \\
\text { Endotoxin } \\
(4 \mu \mathrm{g})\end{array}$ & $\begin{array}{c}4 \cdot 06 \\
(0 \cdot 15) \\
4 \cdot 30 \\
(0 \cdot 05)\end{array}$ & $\ldots$ & $\begin{array}{c}5 \cdot 15 \\
(0 \cdot 16) \\
4 \cdot 29 \\
(0 \cdot 19)\end{array}$ & $\ldots$ & $\begin{array}{l}\cdots \\
\ldots\end{array}$ & $\begin{array}{c}6 \cdot 21 \\
(0 \cdot 29) \\
5 \cdot 23 \\
(0 \cdot 21)\end{array}$ & $\ldots$ & $\begin{array}{c}6 \cdot 71 \\
(0 \cdot 28) \\
5 \cdot 81 \\
(0 \cdot 02)\end{array}$ \\
\hline 10 & $3.2 \times 10^{4}$ & $\begin{array}{l}\text { Control } \\
\text { Endotoxin } \\
(4 \mu \mathrm{g})\end{array}$ & $\begin{array}{c}3.75 \\
(0 \cdot 17) \\
3 \cdot 67 \\
(0.19)\end{array}$ & $\begin{array}{c}4 \cdot 47 \\
(0 \cdot 10) \\
4 \cdot 29 \\
(0 \cdot 19)\end{array}$ & $\begin{array}{c}5 \cdot 95 \\
(0 \cdot 39) \\
4 \cdot 80 \\
(0 \cdot 27)\end{array}$ & $\ldots$ & $\begin{array}{c}6 \cdot 16 \\
(0 \cdot 46) \\
4 \cdot 95 \\
(0 \cdot 90)\end{array}$ & $\ldots$ & $\begin{array}{c}6 \cdot 24 \\
(0 \cdot 22) \\
5 \cdot 65 \\
(0 \cdot 15)\end{array}$ & $\ldots$ \\
\hline 16 & $1.5 \times 10^{4}$ & $\begin{array}{l}\text { Control } \\
\text { Endotoxin } \\
(4 \mu \mathrm{g})\end{array}$ & $\begin{array}{l}\cdots \\
\ldots\end{array}$ & $\begin{array}{c}4.30 \\
(0 \cdot 20) \\
4 \cdot 40 \\
(0 \cdot 15)\end{array}$ & $\begin{array}{c}4 \cdot 86 \\
(0 \cdot 31) \\
4 \cdot 98 \\
(0 \cdot 17)\end{array}$ & $\begin{array}{l}\cdots \\
\ldots\end{array}$ & $\begin{array}{c}5 \cdot 35 \\
(0 \cdot 16) \\
5 \cdot 5 \\
(0 \cdot 38)\end{array}$ & $\begin{array}{l}\cdots \\
\ldots\end{array}$ & $\begin{array}{l}\cdots \\
\cdots\end{array}$ & \\
\hline
\end{tabular}

*Intestine from duodenum to rectum.

Table II. Effect of oral ammonium ferric citrate and transferrin on growth of $C$. jejuni strain 12650 in intestine of endotoxin-pretreated infant mice

\begin{tabular}{|c|c|c|c|c|}
\hline \multirow[b]{2}{*}{ Treatment of animals } & \multicolumn{4}{|c|}{$\begin{array}{l}\text { Campylobacters, } \log _{10} \text { cfu mean } \\
\text { (SD)/intestine at different times }(\mathrm{h}) \\
\text { after bacterial challenge }\end{array}$} \\
\hline & 2 & 6 & 20 & 26 \\
\hline Control & $\begin{array}{c}3 \cdot 65 \\
(0 \cdot 02)\end{array}$ & $\begin{array}{l}5 \cdot 96 \\
(0 \cdot 48)\end{array}$ & $\begin{array}{c}5 \cdot 82 \\
(0 \cdot 20)\end{array}$ & $\begin{array}{l}5 \cdot 83 \\
(0 \cdot 20)\end{array}$ \\
\hline Endotoxin* & $\begin{array}{l}2 \cdot 90 \\
(0 \cdot 02)\end{array}$ & $\begin{array}{c}4 \cdot 44 \\
(0 \cdot 18)\end{array}$ & $\begin{array}{c}4 \cdot 36 \\
(0 \cdot 20)\end{array}$ & $\begin{array}{c}4 \cdot 87 \\
(0 \cdot 13)\end{array}$ \\
\hline $\begin{array}{l}\text { Endotoxin* + ammo- } \\
\text { nium ferric citrate }{ }^{*} \\
0.05 \mathrm{mg} \text { of iron }\end{array}$ & $\begin{array}{r}3.61 \\
(0 \cdot 4)\end{array}$ & $\begin{array}{c}3.76 \\
(0 \cdot 22)\end{array}$ & $\begin{array}{c}4.04 \\
(0.48)\end{array}$ & $\begin{array}{c}5.08 \\
(0 \cdot 15)\end{array}$ \\
\hline $\begin{array}{l}\text { Endotoxin* }+ \text { ammonium } \\
\text { ferric citrate } \dagger ; 0.5 \mathrm{mg} \text { of } \\
\text { iron }\end{array}$ & $\begin{array}{c}4 \cdot 20 \\
(0 \cdot 90)\end{array}$ & $\begin{array}{c}5 \cdot 39 \\
(0.01)\end{array}$ & $\begin{array}{c}5 \cdot 22 \\
(0 \cdot 14)\end{array}$ & $\begin{array}{c}6 \cdot 37 \\
(0 \cdot 23)\end{array}$ \\
\hline Transferrin $\dagger, 0 \cdot 1 \mathrm{mg}$ & $\begin{array}{l}2 \cdot 80 \\
(0 \cdot 05)\end{array}$ & $\begin{array}{c}3 \cdot 74 \\
(0 \cdot 21)\end{array}$ & $\begin{array}{c}3 \cdot 53 \\
(0 \cdot 25)\end{array}$ & $\cdot$ \\
\hline $\begin{array}{l}\text { Endotoxin } *+\text { transferrin }{ }^{\dagger} \\
0.1 \mathrm{mg}\end{array}$ & $\begin{array}{c}2 \cdot 25 \\
(0 \cdot 01)\end{array}$ & $\begin{array}{c}4 \cdot 27 \\
(0 \cdot 15)\end{array}$ & $\begin{array}{c}3 \cdot 15 \\
(0 \cdot 15)\end{array}$ & $\begin{array}{l}4 \cdot 10 \\
(0 \cdot 4)\end{array}$ \\
\hline
\end{tabular}

*8 $\mu \mathrm{g}$ /animal $; 6 \mathrm{~h}$ before campylobacter challenge.

†Given with campylobacters.
O18: $\mathrm{K} 1$ in the peritoneal cavity and blood and to result in a 100 -fold increase in $\mathrm{LD}_{50}$ (VuopioVarkila et al., 1988).

There are no earlier reports on the effects of systemically injected endotoxin on local infectious agents, such as those on the mucosal surfaces of the mammary, pulmonary, urinary or intestinal epithelium. In the present study, the bacteriostatic effect of endotoxin on intestinal mucosal campylobacters was seen simultaneously with the expected decrease in serum iron (Kampschmidt and Upchurch, 1962). Oral iron overload reversed the bacteriostatic effect of endotoxin. For the reversal, however, a high dose of iron, about $50 \mathrm{mg} / \mathrm{kg}$ live weight, was needed. A lower dose of about $5 \mathrm{mg} / \mathrm{kg}$ live weight was ineffective. Parenteral iron caused a delayed reversal of the bacteriostatic effect which was seen only about $20 \mathrm{~h}$ or more after injection and which was never a total reversal. One reason for this delayed reversal effect may be that systemically administered iron has a more indirect effect on the iron balance at mucosal surfaces than iron administered orally.

As inucus colonisers in mice (Field et al., 1981; Lee et al., 1986), campylobacters have to adapt to 
the mucus environment which contains both lactoferrin and transferrin as iron binding compounds (Mason and Taylor, 1978). In studies of experimental and natural mastitis (Harmon et al., 1976), intramammary injections of endotoxin or $E$. coli, caused a 30-fold increase in the amount of lactoferrin produced in the mammary glands. Whether it is the production of iron-binding proteins that is increased or the iron-binding capacity of lactoferrin and transferrin on mucosal surfaces that is changed, is, however, not known. The question of the importance of these phenomena in the bacteriostatic effect of endotoxin needs further research. Transferrin given orally caused a bacteriostatic effect in both control and endotoxin treated animals. The growth of the three campylobacter strains in colostral bovine milk was also completely inhibited but this inhibition was totally reversed by the addition of ferric ammonium citrate $10 \mathrm{mg} / \mathrm{ml}$ (unpublished results). Campylobacters are known to produce both siderophores and outer-membrane proteins (OMPs) probably involved in siderophore binding, when grown in vitro under iron restricted conditions, and they can use siderophores produced by other organisms (Field et al., 1986). Further studies are needed to determine whether OMPs and siderophores are produced in vivo in mice, especially after endotoxin treatment. On the other hand, iron overloading has been shown to increase the virulence of campylobacters (Kazmi et al., 1984; Stanfield et al., 1987), which also provides evidence of the importance of iron in campylobacter infection.

When campylobacter counts were performed

\section{REFERENCES}

Blaser M J, Duncan D J, Warren G H, Wang W-L L 1983 Experimental Campylobacter jejuni infection of adult mice. Infection and Immunity 39: 908-916.

Beery J T, Hugdahl M B, Doyle M P 1988 Colonization of intestinal tracts of chicks by Campylobacter jejuni. Applied and Environmental Microbiology 54: 2365-2370.

Bullen J J 1981 The significance of iron in infection. Reviews of Infectious Diseases 3: 1127-1138.

Caldwell M B, Walker R I, Stewart S D, Rogers J E 1983 Simple adult rabbit model for Campylobacter jejuni enteritis. Infection and Immunity 42: 1176-1182.

Cortell S, Conrad M E 1967 Effect of endotoxin on iron absorption. American Journal of Physiology 213: 43-47.

Elin R J, Wolff S M 1974 The role of iron in nonspecific resistance to infection induced by endotoxin. Journal of Immunology 112: 737-745.

Fauchere J L, Veron M, Lellouch-Tubiana A, Pfister A 1985 Experimental infection of gnotobiotic mice with Campylobacter jejuni: colonisation of intestine and spread to lymphoid and reticulo-endothelial organs. Journal of Medical Microbiology 20 : 215-224. separately on the small intestine and large intestine, a much stronger colonisation of large intestine was seen. This is in accordance with the results of Blaser et al. (1983) and Yrios and Balish (1986) who found the caecum and colon of adult mice to be the most heavily colonised with campylobacters. Although endotoxin treatment caused a significant increase in the duplication time of campylobacters in both the small intestine and in the caecum and colon, the effect was more pronounced in the small intestine. The reason for this is unknown. It may be related to the different effects of endotoxin in different parts of intestinal mucosa, or to the microbial ecology of campylobacters in the intestinal tract, the organism possible being adapted to caecal and colon mucosal surfaces. Endotoxin is known to decrease iron absorption mediated by transferrin and lactoferrin from the small intestine during the first day after endotoxin treatment (Cortell and Conrad, 1967).

Although in the present study the bacteriostatic mechanism of parenterally added endotoxin could not be fully explained, the effect must be nonimmunological, and further research is needed to explain the role of mucosal lactoferrin and transferrin. The present model in which infant mice are pretreated with endotoxin offers a way to analyse non-immunological factors important in the prevention or promotion of colonisation of enteric pathogens.

This work was supported by the Jenny ja Antti Wihuri Foundation.

Field L H, Underwood J L, Pope L M, Berry L J 1981 Intestinal colonization of neonatal animals by Campylobacter fetus subsp. jejuni. Infection and Immunity 33: 884-892.

Field L H, Underwood J L, Berry L J 1984 The role of gut flora and animal passage in the colonization of adult mice with Campylobacter jejuni. Journal of Medical Microbiology 17: 59-66.

Field L H, Headley V L, Payne S M, Berry L J 1986 Influence of iron on growth, morphology, outer membrane protein composition, and synthesis of siderophores in Campylobacter jejuni. Infection and Immunity 54: 126-132.

Harmon R J, Schanbacher F L, Ferguson L C, Smith K L 1976 Changes in lactoferrin, immunoglobulin $\mathrm{G}$, bovine serum albumin, and $\alpha$-lactalbumin during acute experimental and natural coliform mastitis in cows. Infection and Immunity 13: $533-542$.

Kampschmidt R F, Upchurch H F 1962 Effects of bacterial endotoxin on plasma iron. Proceedings of the Society of Experimental Biology and Medicine 110: 191-193.

Kazmi S U, Roberson B S, Stern N J 1984 Animal-passed, virulence-enhanced Campylobacter jejuni causes enteritis in neonatal mice. Current Microbiology 11 : 159-164.

Lane E M, Batchelor R A, Bourgeois A L, Burr D H, Olson J G 
1987 Urine and faecal IgA response during naturally acquired infection with Campylobacter jejuni. Lancet 1: 1141 .

Lee A, O'Rourke J L, Barrington P J, Trust T J 1986 Mucus colonization as a determinant of pathogenicity in intestinal infection by Campylobacter jejuni: a mouse cecal model. Infection and Immunity 51 : 536-546.

Mason D Y, Taylor C R 1978 Distribution of transferrin, ferritin and lactoferrin in human tissues. Journal of Clinical Pathology 31 : 316-327.

McSweegan E, Burr D H, Walker R I 1987 Intestinal mucus gel and secretory antibody are barriers to Campylobacter jejuni adherence to INT 407 cells. Infection and Immunity 55: 1431-1435.

Morrison D C, Ryan J L 1987 Endotoxins and disease mechanism. Annual Review of Medicine 38: 417-432.

McNabb P C, Tomasi T B 1981 Host defense mechanisms at mucosal surfaces. Annual Review of Microbiology 35: 477496.
Shanker S, Lee A, Sorrell T C 1988 Experimental colonization of broiler chicks with Campylobacter jejuni. Epidemiology and Infection 100: 27-34.

Stanfield J T, McCardell B A, Madden J M 1987 Campylobacter diarrhea in adult mouse model. Microbial Pathogenesis 3: $155-165$.

Weinberg E D 1978 Iron and infection. Microbiological Reviews 42: 45-66.

Weinberg E D 1984 Iron withholding: a defense against infection and neoplasia. Physiological Reviews 64: 65-102.

Vuopio-Varkila J, Nurminen M, Pyhälä L, Mäkelä P H 1988 Lipopolysaccharide-induced non-specific resistance to systemic Escherichia coli infection in mice. Journal of Medical Microbiology 25: 197-203.

Yrios J W, Balish E 1986 Colonization and infection of athymic and euthymic germfree mice by Campylobacter jejuni and Campylobacter fetus subsp. fetus. Infection and Immunity 53 : $378-383$. 